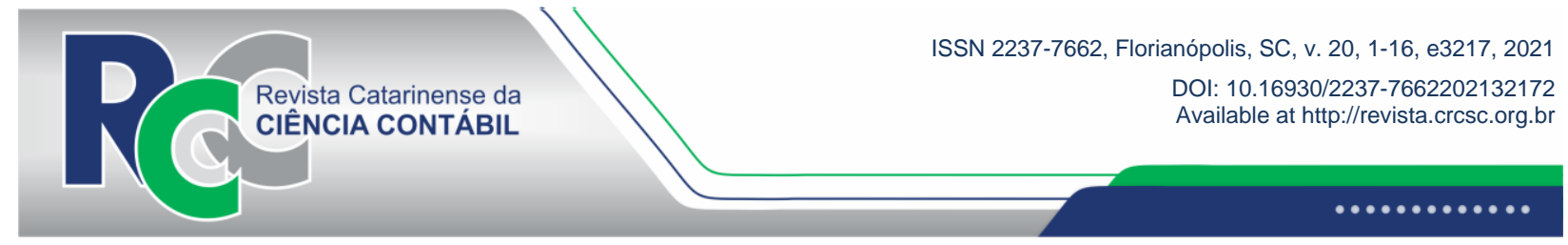

\title{
IMPLEMENTATION OF INTERNATIONAL STANDARDS ON AUDITING BY THE BRAZILIAN COURTS OF AUDITORS
}

\author{
TACIANA CAMILA WITCOSKI ESTEVAM \\ University of Vale do Rio dos Sinos. \\ Address: Av. Dr. Nilo Peçanha, 1600 | Boa Vista | 91330-002 | \\ Porto Alegre/RS | Brazil. \\ (D) https://orcid.org/0000-0002-2978-721X \\ tacy.mila@gmail.com
}

\section{JULIANA DANIELA RODRIGUES}

University of Vale do Rio dos Sinos.

Address: Av. Dr. Nilo Peçanha, 1600 | Boa Vista | 91330-002 |

Porto Alegre/RS | Brasil.

(D) https://orcid.org/0000-0003-2061-2234

julianarodrigs@yahoo.com.br

\section{LEANDRA DA SILVA}

University of Vale do Rio dos Sinos.

Address: Av. Dr. Nilo Peçanha, 1600 | Boa Vista | 91330-002 |

Porto Alegre/RS | Brazil.

(D) https://orcid.org/0000-0003-2741-8397

leandrapoa@yahoo.com.br

\begin{abstract}
This study aimed to analyze the process of implementation of international auditing standards by the Brazilian Courts of Auditors (TCs), through exploratory research and survey, using two questionnaires, with open and closed questions, sent to all TCs and institutions that support their activities. The survey results showed different movements made by the TCs in adhering to the rules, in line with previous research on the practices of Brazilian audit courts and of the Supreme Audit Institutions. Of the 20 TCs responding (61\% of the total), $60 \%$ started the process of implementing the standards, but only $10 \%$ concluded. The international auditing standards whose implementation is more advanced are the NBASP 20 and 30, which bring the principles of transparency and accountability together with the management of ethics by the TCs. The findings regarding the wide availability of training on the subject, the support provided by organizations, and the absence of the need to use financial resources for implementation by the bodies that completed the process, raise doubts about the motivations of the TCs that did not initiate the process. Despite the efforts made to qualify the performance of the TCs, there seems to be a long way to go towards completing the implementation in the country due to the lack of forecast by most respondents.
\end{abstract}

Keywords: Court of Auditors. Audit. NBASP. ISSAI. Implementation.

Edited in Portuguese and English. Original version in Portuguese.

Received on 10/26/2021. Reviewed on 12/6/2021. Accepted on 12/19/2021 by Prof. Dr. Sérgio Murilo Petri (Editor-in-Chief) and Prof. Dr. Sandro Vieira Soares (Associate Editor). Published on 12/29/2021.

Copyright $\odot 2021$ RCCC. All rights reserved. Quoting parts of articles without prior authorization is allowed, as long as the source is identified. 


\section{INTRODUCTION}

In recent years, in the mist of the disclosure of several corruption cases in Brazil, great attention has been given to the work of the Public Administration's control bodies. The role of the Audit Courts (TC, as per their Portuguese Acronym), the Supreme Audit Institutions (SAIs), is fundamental in this context, as they have the potential to help improve government performance, grow democracy, and increase citizens' trust in the quality of public resource management (Gørrissen, 2020; Dragustin, Pitulice, \& Stefanescu, 2021).

Simultaneously, the Brazilian public sector has undergone reforms with regard to the standards and procedures used, seeking to adapt to international standards. Regarding accounting, many actions have recently taken place for the adoption of International Public Sector Accounting Standards (IPSAS, per its Portuguese Acronym), involving efforts by all federative entities, as well as coordination movements led by the Federal Accounting Council (CFC, per its Portuguese acronym) and the Office of the National Treasury (STN, per its Portuguese acronym), which began in the year 2008 (STN, 2018).

As in accounting, public-sector auditing has organizations that support its activities and influence the process of convergence to new standards (Hay \& Cordery, 2020). Internationally, the International Organization of Supreme Audit Institutions (INTOSAI) is the institution that proposes the International Standards for Supreme Audit Institutions (ISSAIs) and has been increasing its legitimacy with over 70 years of operation (Reichborn-Kjennerud et al., 2019). In Brazil, the process of adopting INTOSAI standards has been conducted through a partnership between the Federal Court of Auditors (TCU) and Instituto Rui Barbosa Institute (IRB), through the creation of the Brazilian Public Sector Auditing Standards (NBASP, per its Portuguese acronym) (TCU, 2020a).

The adoption of international auditing standards in the public sector can promote several benefits, thus involving greater perception of the quality of work, more effective control of public resources and the generation of a language that favors the exchange of experiences between different countries (López-Hernández, 2013). The use of auditing standards that are internationally recognized by the TCs is an important tool for improving Brazilian control and public management, resulting in institutional strength (TCU, 2020b).

Such benefits become even more relevant in the context of recent scandals, such as illicit gains by councilors of the Audit Court of the State of Rio de Janeiro (TCE-RJ, per its Portuguese acronym) and the prevalence of poor organizational practices, as studied by Lino and Aquino (2020). Another factor that corroborates the need for a performance standard for TCs are the different interpretations in the judgments applied to jurisdictional entities, which have hindered the effectiveness of fiscal risk mitigation rules for federal entities (Nunes, Marcelino, \& Silva, 2019).

However, recent research suggests that adopting international standards applied to public sector auditing is still incipient, with great divergences between the procedures applied in the case of Brazilian TCs (Azevedo \& Lino, 2018; Lino \& Aquino, 2018). There is currently no mandatory adoption of NBASP in the country, and each court can prepare distinct movements for the adoption of the standards. According to the literature, despite many higher oversight bodies associated with INTOSAI, the international use of its standards is still far from reaching the entirety of its members (Kontogeorga, 2019; Manes-Rossi, Brusca, \& Condor, 2020; Cordery \& Hay, 2021).

That said, considering the importance of the work of the Audit Courts for the quality of Brazilian public management and the benefits from the adoption of international standards, the interest arose to understand how each body is acting in the face of the process, in order to identify their challenges, best practices and improvements in audit activities. In this sense, this study aimed to analyze the adoption of international public sector auditing standards by Brazilian TCs and the support provided by professional organizations in the field. 
The literature on auditing in the public sector is still scarce, which is surprising given that the sector represents a large portion of the institutions audited (Hay \& Cordery, 2021). Moreover, despite the growing interest in research about the different practices among the suprem audit institutions, either internationally (Manes-Rossi, Brusca, \& Condor, 2020; Cordery \& Hay, 2021), or in Brazilian TCs (Azevedo \& Lino, 2018; Lino \& Aquino, 2018; Lino \& Aquino, 2020; Nunes, Marcelino, \& Silva, 2019; Luz, Guarido, \& Sousa, 2021), while conducting this research, we were not aware of any works that address the progress of the international standard implementation process by the competent bodies.

This study seeks to fill a gap in the subject, specifically regarding the adoption of international auditing standards in the public sector, exploring the scenario of the convergence process in Brazil and providing a basis to analyze the diversity of movements and their possible causes. Additionally, the information provided in this study may be useful for planning actions by national and international bodies in order to accelerate the adoption of the standards, implementing adjustments to increase the quality of inspection with the aim of better justifying revenues and expenditures to society.

The study is organized into five sections, including this introduction. The second section presents the theoretical and empirical review of the International Public Sector Auditing Standards. The third section describes the methodological procedures adopted in the research. The results are reported in the fourth section, with considerations being presented in the fifth section.

\section{THE SUPREM AUDIT INSTITUTIONS AND THE INTOSAI STANDARDS}

Suprem audit institutions (SAIs) are old and traditional institutions, with operation provided by the Constitution of the jurisdiction, evolving over the years, but reflecting long-term culture and traditions (Caruana \& Kowalczyk, 2021). Each country usually has specific regulations around the organization, activities, and responsibilities of such bodies, according to its contextual reflections (Manes-Rossi, Brusca, \& Condor, 2020).

In Brazil, TCs are the top inspection entities and act in the external control of public resources of the three spheres of government (Luz, Guarido, \& Sousa, 2021). The Federal Audit Court (TCU) was established in a definitive way after the first republican Constitution, in 1891 (Speck, 2000). After that, state and municipal TCs were created, and there are currently 33 such bodies in the country.

The SAIs can be organized as a Court of Auditors with judicial functions and powers to impose sanctions, as in the case of the Brazilian TCs and also in countries such as France, Italy, and Portugal; they can be collegiate bodies without judicial functions and powers to impose sanctions, as in the case of Germany and the Netherlands; and a third form is an auditor general appointed to head independent audit offices, as in the United Kingdom and Denmark, or offices outside the government structure, as in Finland (Caruana \& Kowalczyk, 2021).

The organization of auditing applied to the public sector is strongly based on the vision of a democratic contract, because the existence of agents performing audits that seek to ensure the government's performance, in accordance with the applied legislation and political objectives, increases the credibility that work on behalf of society will be done in a way that meets its expectations (Gustavson \& Rothstein, 2013). Auditors are charged with checking whether public resources are being used responsibly and effectively, which helps government entities in their accountability and the trust of citizens and other stakeholders. Therefore, good auditing is critical to avoid mismanagement of public resources (Manes-Rossi, Brusca, \& Condor, 2020).

Each country has its own auditing standards, with those that adhere to international standards, applicable to the public or private sector, and those that adopt their own standards, which may be based on international standards (Manes-Rossi, Brusca, \& Condor, 2020). However, the goals of audits conducted in governments differ from the objectives of audits performed in 
other organizations, thus limiting the use of non-specific standards (Azuma, 2008). Despite the differences between auditing in the public and private sectors, a key point for its quality is the auditor's independence, which the standards seek to protect. The importance of ensuring the integrity of those involved for effective accountability and lower risks of misappropriation of resources is evident (Caruana \& Kowalczyk, 2021).

SAIs possess strengthened professional bodies, which have been acting beyond class representation and are inserted in the discussion about the improvement of the bodies' performance (Reichborn-Kjennerud et al., 2019; Hay \& Cordery, 2020; Luz, Guarido, \& Sousa, 2021). Internationally recognized auditing standards applied to the public sector are currently issued by the International Organization of Supreme Audit Institutions (INTOSAI), which classifies itself as one of these supporting organizations.

INTOSAI was founded in 1953, during a congress that brought together SAIs from 34 countries, including Brazil (TCU, 2020).It currently has 195 member countries, plus five associated organizations and one affiliated country (INTOSAI, 2021). Its performance is independent, professional and without political ties, with the aim of establishing mutual support, exchanging information, acting as international representation of the Courts of Auditors, and strengthening institutions with good governance, development of performance and quality audit standards for the public sector (INTOSAI, 2021).

The International Standards of Supreme Audit Institutions (ISSAIs) stem from work that began in 2004, and is under constant review, to build the capacities and structures necessary to organize a set of international standards for public sector auditing (INTOSAI, 2021). The standardization proposed by INTOSAI seeks to provide homogeneity and credibility to external audits in the public sector, thus, bringing things such as the quality of work, credibility for users, process improvement, transparency, auditor accountability, among others (Dragustin, Pitulice, \& Stefanescu, 2021). The framework of the INTOSAI professional standards has four levels, as described by TCU (2020b):

a) ISSAI Level 1: addresses the fundamental principles.

b) ISSAI Level 2: addresses the requirements related to the proper functioning of SAIs and the conduct of their professionals, addressing points such as independence, transparency and accountability, ethics, and quality control.

c) ISSAI Level 3: arising from ISSAI 1 (Lima Declaration) and Level 2 ISSAIs, it defines governmental auditing and proposes the international normative structure reference.

d) ISSAI Level 4: provides more objective operational guidelines to portray the fundamental principles of auditing, allowing for use in auditing routines and in developing auditing standards.

The different political, social, cultural, and economic realities of SAIs make it challenging to have a model that is suitable for all (Caruana \& Kowalczyk, 2021, Cordery \& Hay, 2021). In this context of heterogeneity, INTOSAI encourages countries to implement the standards according to their own (INTOSAI, 2021). In Brazil, the first publication of the Brazilian Auditing Standards in the Public Sector (NBASP) took place in 2015, based on a convergence that used the standards approved by INTOSAI and included references from the Audit Standards of the Federal Court of Auditors (NAT, per its Portuguese acronym), the Government Auditing Standards (NAG, per its Portuguese acronym), the resolutions of the Association of Members of the Brazilian TCs (Atricon, per its Portuguese acronym), and the legislation in force in the country.

In line with the importance of class organizations for the performance of SAIs (ReichbornKjennerud et al., 2019; Hay \& Cordery, 2020; Luz, Guarido, \& Sousa, 2021), the initiative to issue the standards came from the IRB, a civil association created in 1973, with the aim of assisting TCs in improving and better developing their activities (IRB, 2020). The TCU also had an important participation in the process with the translation of INTOSAI's standards, which were reviewed by the IRB's Auditing Standards Subcommittee for the publication of the NBASP (TCU, 2020a). The 
NBASP are organized into three levels (IRB, 2019), which do not have an exact correspondence with the levels presented by the ISSAIs:

a) NBASP Level 1 - Fundamental principles and requirements for the operation of TCs: relate to levels 1 and 2 of the ISSAIs framework in force in 2013, with five standards that bring organizational requirements for audit work.

b) NBASP Level 2 - Fundamental principles of auditing: relate to level 3 of the ISSAIs structure in force in 2013. There are four standards that involve the objectives and the referential framework of the inspections, through the definition of the elements whose presence in the work is mandatory, and the principles to be observed throughout the process.

c) NBASP Level 3 - Mandatory audit requirements: relate to level 4 of the ISSAIs structure in force in 2013. Two standards were made available in 2019 and made the principles found in the previous level's standards mandatory requirements.

Notwithstanding the consolidation of the publishing of the standards by the IRB, since 2015, the implementation and effective use by TCs needs to occur so that the benefits of international auditing standards can be observed in the country. The application of the new standards may not be a simple and fast task, requiring sufficient human and material resources, as well as an implementation strategy (López-Hernández, 2013). Despite the challenges pointed out, the literature dedicated to studying the process of adopting INTOSAI's standards nationally and internationally is scarce, and while conducting this research, we were not aware of any works that address the lack of correspondence between audit practices.

Recent studies are dedicated to comparing the different practices used by Brazilian TCs, showing the lack of standardization among different jurisdictions and in the work of auditors of a same body (Azevedo \& Lino, 2018; Lino \& Aquino, 2018; Lino \& Aquino, 2020; Nunes, Marcelino, \& Silva, 2019; Luz, Guarido, \& Sousa, 2021). Moreover, the low use and undersized knowledge of NBASP were found in empirical work by Azevedo and Lino (2018), in which possible difficulties in implementing the standards are pointed out.

Differences are also seen in the international scenario. In a survey answered by the SAIs from INTOSAI member countries, Cordery and Hay (2021) found that 55\% used the ISSAIs, while the others used different references. International auditing standards lack correspondence even within a same region, as is the case of Europe, which was studied by Manes-Rossi, Brusca, and Condor (2020). Moreover, even with the accelerated development of auditing standards, many SAls have faced challenges in implementing improvements in their procedures (Gørrissen, 2020).

Given the importance of the work of the TCs for the good application of public resources and its consequent impact on the welfare of the Brazilian population, the attempt to qualify its activities by using international standards was analyzed for this work, whose methodological procedures are described in the following section.

\section{METHODOLOGICAL PROCEDURES}

This research is classified as exploratory, survey and qualitative-quantitative. The methodological procedures are described in Figure 1. The population studied to analyze the implementation of international audit standards in Brazil involved the 33 existing TCs: one TCU, 27 state TCs, three TCs of municipalities and two municipal TCs, and seven organizations that support auditing activities in the Public Administration: the Brazilian Association of Municipal Audit Courts (Abracom, per its Portuguese acronym), Association of Members of the Audit Courts of Brazil (Atricon), National Association of Ministers and Deputy Councilors of Audit Courts (Audicon, per its Portuguese acronym), National Council of Presidents of Audit Courts (CNPTC, per its Portuguese acronym), Federal Accounting Council (CFC, per its Portuguese acronym), Institute of Independent Auditors of Brazil (Ibracon, per its Portuguese acronym) and Instituto Rui 
Barbosa (IRB), given the relevance of such entities for the reinforcement of the work of TCs as shown by the literature on the subject (Reichborn-Kjennerud et al., 2019; Hay \& Cordery, 2020; Luz, Guarido, \& Sousa, 2021).

Data collection was conducted through questionnaires forwarded via the Information Access Portal and/or via e-mail, in the period from September 6 to September 12, 2020. Responses were received from September 10 to October 27, 2020. Of the 40 institutions consulted, 26 responded to the questionnaire, with the sample totaling $65 \%$ of the total, with six supporting bodies and 20 TCs. Among those who did not respond, there were two rejections of the requests on the grounds that they do not collaborate with academic research due to internal rules; two rejections on the grounds of some kind of registration problem and, despite sending an appeal, there was no return; three confirmations of receipt with no return; and the others did not confirm receipt.

\begin{tabular}{|c|c|c|}
\hline \begin{tabular}{|l|} 
Stage 1 - Preparation of the Questionnaires \\
\end{tabular} & Step 2 - Data Collection & Step 3 - Analysis of Responses \\
\hline Q1 - Supporting organizations & Sending & Qualitative Analysis \\
\hline $\begin{array}{l}\text { - Open questions: form of support, motivation, } \\
\text { challenges, benefits, schedule, resources, joint } \\
\text { action (López-Hernández, 2013; Gørrissen, } \\
\text { 2020). }\end{array}$ & $\begin{array}{l}\text { Submission to the } 33 \mathrm{TCs} \text { and } \\
\text { seven supporting organizations } \\
\text { via the Information Access } \\
\text { Portal and/or email (6 to } \\
12 / 09 / 2020) \text {. }\end{array}$ & $\begin{array}{l}\text { Bardin (2011) content analysis } \\
\text { technique, with categories built } \\
\text { according to the answers of the open } \\
\text { questions. }\end{array}$ \\
\hline Q2 - Audit Courts & Response & Quantitative analysis \\
\hline $\begin{array}{l}\text { - Closed question: general implementation } \\
\text { status. } \\
\text { - Open questions contextualized to the status of } \\
\text { the process: motivation, challenges, resources, } \\
\text { rules, deadline, benefits (López-Hernández, } \\
\text { 2013; Gørrissen, 2020). } \\
\text { - Closed-ended question on the status of each } \\
\text { standard. }\end{array}$ & $\begin{array}{l}\text { Responses received from } \\
\text { supporting agencies and } 20 \\
(10 / 09 \text { a 27/10/2020). }\end{array}$ & $\begin{array}{l}\text { Frequency analysis of the respons } \\
\text { to the closed questions. }\end{array}$ \\
\hline
\end{tabular}

Figure 1. Methodological procedures.

Source: prepared by the authors.

Two different questionnaires were prepared and are identified as Questionnaire 1(Q1) and Questionnaire $2(\mathrm{Q} 2)$ throughout the presentation of results, the former being specific to the institutions that support the financial and auditing of the Brazilian public sector and the latter specific to the TCs. Both instruments contain open-ended questions addressing how they are supporting/conducting the process, what their motivations, challenges and expected benefits are, and how they are organizing themselves in terms of formalization, schedules, and human and financial resources, issues reported by the literature as necessary for the implementation of the standards (López-Hernández, 2013, Gørrissen, 2020).

Q2 begins with a closed main question that inquires the current status of the implementation of international auditing standards in the TC, i.e., whether it has been initiated, is being studied, is in progress, or has been completed. For each of the options, open questions were related to the status of the process in the body, addressing the points brought up in the previous paragraph, in addition to closed questions concerning the status of the implementation of each of the standards for the cases in which work has been initiated or concluded.

In the first stage of the research, the questionnaires were submitted for face and content validation by specialists in the theme and were analyzed by three auditors who work in TCs in the country. The questionnaires were reformulated to achieve better effectiveness in their application according to the notes received. The answers received were analyzed quantitatively through the frequency analysis of the answers to the closed questions, and qualitatively, through the content analysis technique (Bardin, 2011), with categories built according to the answers for each point analyzed by the open questions, as presented in the tables of section 4 . 


\section{ANALYSES OF THE RESULTS}

\subsection{Implementation of international auditing standards in Audit Courts}

In addition to the stage of implementing each of the standards in the courts, it is important to know the measures taken by each body for the adequacy to international standards. The actions taken by the supporting institutions in this process were also analyzed given the relevance of professional organizations for the activities of the superior inspection entities (ReichbornKjennerud et al., 2019; Hay \& Cordery, 2020; Luz, Guarido, \& Sousa, 2021).

Thus, for the supporting institutions (Q1), information was requested about how they are acting in promoting the use of NBASP, the main reason that led the institution to act in the implementation process, which agencies have acted jointly to support the adoption process, how these interactions are happening, what financial resources were or would be used to start the implementation process, and the possible existence of a schedule for guiding the process in all TCs. These responses are listed in Table 1.

The results indicated that the support provided for the implementation of the standards lies mainly in the provision of training and guidance, something consistent with the literature (Reichborn-Kjennerud et al., 2019; Hay \& Cordery, 2020). Joint action between national and international organizations was verified, and that the motivations for supporting the process were in line with qualification and legitimization (Cordery \& Hay, 2021).

Regarding the financial resources used, none of the supporting institutions presented expenses. As for the existence of a activity coordination schedule, one of the organizations reported the existence of a schedule with an estimate for concluding the convergence in 2021, which will possibly not be achieved by all the TCs, given the proximity of the date and the current situation verified in the study.

Table 1

Responses from supporting institutions regarding the international auditing standards in the Courts of Auditors

\begin{tabular}{|c|c|c|}
\hline Question & $\begin{array}{l}\text { No. of } \\
\text { response } \\
\text { S }\end{array}$ & Reasons provided by the institutions \\
\hline $\begin{array}{l}\text { Encouragement for } \\
\text { using NBASP }\end{array}$ & 6 & $\begin{array}{l}\text { They promote, participate, or offer courses, forums, seminars with the } \\
\text { intention of disseminating the NBASP and providing guidance on auditing } \\
\text { in specific fields. }\end{array}$ \\
\hline \multirow{4}{*}{$\begin{array}{l}\text { Motivation to support } \\
\text { the standard } \\
\text { implementation } \\
\text { process. }\end{array}$} & 3 & $\begin{array}{l}\text { Acceptance of audit work in any jurisdiction and alignment with the main } \\
\text { national and international audit bodies. }\end{array}$ \\
\hline & 1 & $\begin{array}{l}\text { Qualification of audit work and, consequently, improvement in service } \\
\text { and trust from the population. }\end{array}$ \\
\hline & 1 & $\begin{array}{l}\text { Central coordination position, occupied by the institution, before the } \\
\text { system. }\end{array}$ \\
\hline & 1 & No response. \\
\hline \multirow{3}{*}{$\begin{array}{l}\text { Institutions involved } \\
\quad \text { and means of } \\
\text { interaction for support. }\end{array}$} & 4 & $\begin{array}{l}\text { Abracom, Atricon, Audicon, CNPTC, CFC, Ibracon and IRB. The } \\
\text { interactions between the bodies takes place daily and harmoniously in the } \\
\text { various actions promoted, mostly as a single body. }\end{array}$ \\
\hline & 1 & $\begin{array}{l}\text { Intosai, IIA (The Institute of Internal Auditors), World Bank, IFAC } \\
\text { (International Federation of Accountants). }\end{array}$ \\
\hline & 1 & No response. \\
\hline \multirow{4}{*}{$\begin{array}{l}\text { What financial } \\
\text { resources were or will } \\
\text { be used to initiate the } \\
\text { process. }\end{array}$} & 4 & $\begin{array}{l}\text { IRB would provide the implementation cost, and each of the TCs would } \\
\text { allocate part of the budget. }\end{array}$ \\
\hline & 1 & Indirect participation, unaware of expenses. \\
\hline & 1 & No response. \\
\hline & 5 & A schedule was not prepared since each $\mathrm{TC}$ was to organize internally. \\
\hline
\end{tabular}


Existence of a schedule with the beginning and end of the implementation.
1

The year 2021 is indicated in the schedule as the year of conclusion for the first phase of the convergence process of all NBASPs.

Source: prepared with data from the answers to Q1 of the survey.

In the questionnaire sent to the TCs (Q2), the questions were prepared based on the current status of the NBASP implementation process in the body. Responses were received from $60 \%$ (20) of the $33 \mathrm{TCs}$, and the questions were based on the status of the international auditing standard implementation process. Figure 2 illustrates the status of the process at the time of the survey.

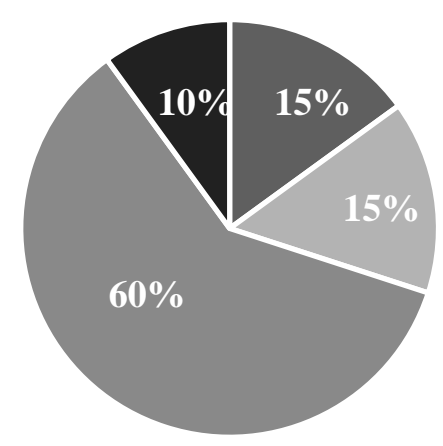

- Não iniciado

- Sendo estudado

- Em andamento

- Concluído

Figure 2. Situation of the NBASP implementation process in the Audit Courts

Source: prepared with data from the answers to Q2 of the survey.

It is noteworthy that $15 \%$ (3) of the TCs in the sample reported that they have not yet initiated the standard implementation process, and 15\% (3) were at an early stage of studies, which allows us to infer that $30 \%$ (6) have not yet used the international standards. Most of the respondents informed that the implementation was in progress (12, or $60 \%$ of the sample) and only $10 \%$ (2) concluded the process. Therefore, it was found that $70 \%$ (14) of the responding TCs observed at least part of the international auditing standards. The heterogeneity of the movements observed was consistent with recent research on the different practices of Brazilian TCs (Azevedo \& Lino, 2018; Lino \& Aquino, 2018; Lino \& Aquino, 2020; Nunes, Marcelino, \& Silva, 2019; Luz, Guarido, \& Sousa, 2021) and international SAIs (Manes-Rossi, Brusca, \& Condor, 2020; Cordery \& Hay, 2021).

The results for each of the situations in the process of meeting the standards are presented based on the first analysis, considering that, for each status, there are a number of different questions, since the closer to the conclusion of the process, the more information can be gathered. Table 2 shows the steps taken by each TC for the implementation.

Table 2 displays the results for the three TCs (15\%) that reported that the adoption of NBASP has not been initiated. They were asked about the main reasons why the body has not initiated the process and if there is a timeline for the beginning of the work. The TCs informed that there was not yet a start date and reported difficulties such as the presidency's lack of determination and the need for human and material resources. The results were consistent with the challenges faced when implementing standards, pointed out by the literature, highlighting the importance of leadership and organizational capacity (López-Hernández, 2013, Gørrissen, 2020).

The second situation reports the results for the three TCs $(15 \%)$ that reported they were studying the possibility of adopting the standards. For this situation, the question asked revolved around the existence of professionals involved in evaluating the possibility of initiating the process, whether there was a study on the need for the use of financial resources, and the main 
objections that prevented the NBASP implementation from commencing. According to the answers, two courts have already put together human resources for the project but encountered the Covid-19 pandemic (2) and the absence of internal regulations determining adherence to the standards (1) as obstacles.

The third situation shown turned to the 12 TCs $(60 \%)$ that whose implementation process was underway. They were then asked about the main reason for starting the process, the number of professionals allocated, the need for financial resources, whether the court had rules on adherence, the time it would take to fully implement the standards, and which ones had been implemented by the body. The information regarding the reason the adoption process was initiated is one of the IRB's technical objectives, which states that the use of NBASP consists in the "importance of professional standards for the credibility, quality and professionalism of public sector auditing" (IRB, 2020). According to the deadline indicated in the schedule mentioned by one of the supporting institutions, two more TCs should complete the implementation by the end of 2021. It is emphasized that the estimated time for completion was not answered by ten courts, which led to the understanding that the implementation of NBASP is not something easy and quick to accomplish (López-Hernández, 2013; Kontogeorga, 2019; Gørrissen, 2020).

The fourth situation presented is that of the two TCs (10\%) that have already completed the process of implementing the standards. For this situation, the question asked addressed the reason that led the body to start the process, the number of professionals allocated, the need for financial resources, whether there were regulations dealing with adherence, and the time taken to complete the process. The main motivation mentioned was the importance of standardization for the quality of the work.

There were indications regarding the importance of the existence of an internal regulation dealing with adherence to standards, since it was widely observed in the TCs in progress (9) or with standards that were completed (2), while its absence was presented as an obstacle by one of the TCs that did not initiate the process. The cause for this may be related to the conventions of the Public Administration, but also to the importance of leadership and planning for the success of the adoption (López-Hernández, 2013; Gørrissen, 2020). The use of material resources, defended as a deterrent by the TCs that did not start implementing the standards, was not intensive by the TCs that are advancing in the process, leaving doubts about the relevance of its need for implementation, at least in some contexts.

Table 2

Measures taken by each TC for the implementation of the international auditing standards

\begin{tabular}{|c|c|c|c|}
\hline Status & Question & $\begin{array}{l}\text { No. of } \\
\text { responses }\end{array}$ & Responses from courts \\
\hline \multirow{2}{*}{ 乙。 } & $\begin{array}{l}\text { Main } \\
\text { reasons }\end{array}$ & 3 & $\begin{array}{l}\text { Lack of determination from the presidency, difficulties with the } \\
\text { information system, knowledge, training, and lack of technical staff. }\end{array}$ \\
\hline & Estimate & 3 & There is no estimate. \\
\hline \multirow{5}{*}{ 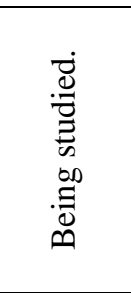 } & \multirow{2}{*}{$\begin{array}{l}\text { Human } \\
\text { Resources }\end{array}$} & 1 & A team to conduct the project was not formally appointed. \\
\hline & & 2 & Civil servants were appointed for the studies. \\
\hline & $\begin{array}{l}\text { Financial } \\
\text { resources }\end{array}$ & 3 & Costs for this process were not yet estimated. \\
\hline & \multirow{2}{*}{$\begin{array}{c}\text { Obstacles } \\
\text { to the } \\
\text { process. }\end{array}$} & 2 & Covid-19 pandemic. \\
\hline & & 1 & Lack of internal rule determining the TC be aligned with the NBASP. \\
\hline \multirow{3}{*}{ 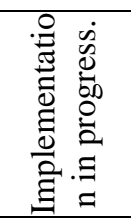 } & \multirow{3}{*}{$\begin{array}{l}\text { Process } \\
\text { motivation. }\end{array}$} & 4 & $\begin{array}{l}\text { Alignment of methods and techniques and guarantee and techniques and } \\
\text { guarantee of uniformity in procedures. }\end{array}$ \\
\hline & & 5 & $\begin{array}{l}\text { Increase in the quality of inspection processes and credibility before } \\
\text { users. }\end{array}$ \\
\hline & & 2 & Perfection of external control and adhesion to the world movement. \\
\hline
\end{tabular}




\begin{tabular}{|c|c|c|c|}
\hline & & 1 & Participation in institutional projects of the Audit Court system. \\
\hline & \multirow{4}{*}{$\begin{array}{l}\text { Human } \\
\text { Resources }\end{array}$} & 5 & From 1 to 5 employees. \\
\hline & & 2 & From 6 to 10 employees. \\
\hline & & 3 & Above 10 employees. \\
\hline & & 2 & Did not respond. \\
\hline & \multirow{3}{*}{$\begin{array}{l}\text { Financial } \\
\text { resources }\end{array}$} & 7 & No financial resources were used in the process. \\
\hline & & 1 & No financial resources were used, but it may occur. \\
\hline & & 4 & Costs with consultancy, trips for training and process redesign. \\
\hline & \multirow[t]{2}{*}{ Specific rule } & 3 & $\begin{array}{l}\text { Do not have: (1) awaiting completion of the implementation; (2) being } \\
\text { studied. }\end{array}$ \\
\hline & & 9 & Have rules. \\
\hline & \multirow{3}{*}{$\begin{array}{l}\text { Completion } \\
\text { deadline }\end{array}$} & 1 & End of 2020 \\
\hline & & 1 & End of 2021 \\
\hline & & 10 & Did not inform. \\
\hline \multirow{8}{*}{ 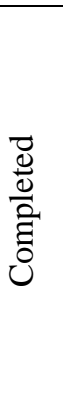 } & $\begin{array}{l}\text { Process } \\
\text { motivation. }\end{array}$ & 2 & Importance of standardization for the quality of work. \\
\hline & \multirow{2}{*}{$\begin{array}{c}\text { Human } \\
\text { Resources }\end{array}$} & 1 & All auditors are active (quantity not reported). \\
\hline & & 1 & 6 auditors. \\
\hline & \multirow{2}{*}{$\begin{array}{l}\text { Financial } \\
\text { resources }\end{array}$} & 1 & No financial resources were used in the process. \\
\hline & & 1 & No response. \\
\hline & Specific rule & 2 & Have rules. \\
\hline & \multirow{2}{*}{$\begin{array}{l}\text { Deadline for } \\
\text { implementati } \\
\text { on. }\end{array}$} & 1 & 2 years duration. \\
\hline & & 1 & 3 years duration. \\
\hline
\end{tabular}

Source: prepared with data from the responses to Q2 of the survey.

Table 3 reflects answers to the question involving which standards have already been implemented by the TCs, which indicates the situation of each of the NBASP and ISSAIs that have not converged, arising from the closed question in which the respondent should mark the option referring to each of the standards. Table 3 shows that NBASP 20, which deals with transparency and accountability, and NBASP 30, which deals with ethics management, were the most implemented.

The result may indicate the TCs' concern with accountability. However, a high volume of bodies that did not cooperate with this question was observed, confirming the study of Macagnan, Laureano, Rosso and Wartchow (2019), who mention a behavior of transparency and accountability by the TC's that is not exemplary, therefore leading to deficiencies in public governance, in addition to the controversies arising from the practices that are objected to in their performances (Lino \& Aquino, 2020). These deficiencies do not contribute society's trust in the TCs, nor to that of other countries that may come to perform transactions with Brazil, points which will be positively influenced by the international standards.

Table 3

Status of the implementation of standards in each Audit Court

\begin{tabular}{|c|c|c|c|c|c|c|}
\hline \multicolumn{2}{|c|}{$\begin{array}{c}\text { Standards that are converged in } \\
\text { Brazil (NBASP) }\end{array}$} & \multicolumn{5}{|c|}{ Status } \\
\hline $\begin{array}{l}\text { NBASP } \\
\text { (converged) }\end{array}$ & $\begin{array}{l}\text { ISSAIs } \\
\text { (original) }\end{array}$ & $\begin{array}{c}\text { Not } \\
\text { initiated }\end{array}$ & In progress & $\begin{array}{c}\text { Implemente } \\
\text { d }\end{array}$ & No response & Total \\
\hline NBASP 10 & ISSAI 10 & & 3 & 3 & 6 & 12 \\
\hline NBASP 12 & ISSAI 12 & & 5 & 1 & 6 & 12 \\
\hline NBASP 20 & ISSAI 20 & & 3 & 4 & 5 & 12 \\
\hline NBASP 30 & ISSAI 30 & & 2 & 5 & 5 & 12 \\
\hline NBASP 40 & ISSAI 40 & 2 & 2 & 3 & 5 & 12 \\
\hline NBASP 100 & ISSAI 100 & & 6 & 3 & 3 & 12 \\
\hline NBASP 200 & ISSAI 200 & 1 & 6 & 2 & 3 & 12 \\
\hline NBASP 300 & ISSAI 300 & & 6 & 3 & 3 & 12 \\
\hline
\end{tabular}




\begin{tabular}{|c|c|c|c|c|c|c|}
\hline NBASP 400 & ISSAI 400 & 1 & 5 & 3 & 3 & 12 \\
\hline NBASP 3000 & ISSAI 3000 & & 5 & 2 & 5 & 12 \\
\hline NBASP 4000 & ISSAI 4000 & 1 & 4 & 2 & 5 & 12 \\
\hline \multicolumn{2}{|c|}{$\begin{array}{c}\text { Standards not converged in } \\
\text { Brazil } \\
\end{array}$} & $\begin{array}{c}\text { Not } \\
\text { initiated }\end{array}$ & In progress & $\begin{array}{c}\text { Implemente } \\
\text { d }\end{array}$ & No response & Total \\
\hline \multicolumn{2}{|c|}{ ISSAI 1} & & 2 & 2 & 8 & 12 \\
\hline \multicolumn{2}{|l|}{ ISSAI 11} & 1 & 2 & 2 & 7 & 12 \\
\hline \multicolumn{2}{|l|}{ ISSAI 21} & 1 & 3 & 2 & 6 & 12 \\
\hline \multicolumn{2}{|l|}{ ISSAI 3100} & 2 & 3 & 1 & 6 & 12 \\
\hline \multicolumn{2}{|c|}{ Appendix ISSAI 3100} & 2 & 3 & 1 & 6 & 12 \\
\hline \multicolumn{2}{|l|}{ ISSAI 3200} & 2 & 3 & 1 & 6 & 12 \\
\hline
\end{tabular}

Source: prepared with data from the answers to Q2 of the survey.

NBASP 100, 200, 300, 400 and 3000 also came to attention, each dealing with the financial and operational aspects of the auditing process that seemed closer to being concluded and tend to qualify the performance of the bodies. In relation to the standards that have not yet been converged in Brazil, Table 3 shows that some TCs observed them or were working towards their use, despite not being expressly included in the national movement toward the adoption of standards.

\subsection{Improvements with the implementation of the International Standards on Auditing (NBASP)}

This subsection presents the results in relation to the improvements that the implementation of NBASP can offer Brazil vis-à-vis other countries and society. Table 4 shows the improvements mentioned by the responding supporting institutions (Q1) and TCs (Q2).

Table 4

Improvements described by supporting institutions and courts

\begin{tabular}{|c|c|c|c|}
\hline $\begin{array}{l}\text { Question } \\
\text { s }\end{array}$ & $\begin{array}{l}\text { Target of } \\
\text { improvement } \\
\quad \text { S }\end{array}$ & $\begin{array}{l}\text { No. of } \\
\text { responses }\end{array}$ & Improvements pointed out by the institutions \\
\hline \multirow{7}{*}{ 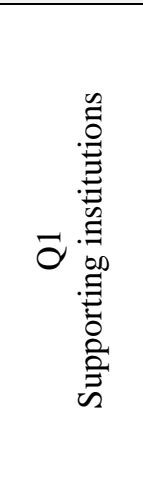 } & \multirow{5}{*}{$\begin{array}{l}\text { Brazil before } \\
\text { other } \\
\text { countries }\end{array}$} & 1 & Credibility for control bodies and governments \\
\hline & & 1 & $\begin{array}{l}\text { Recognition and improvement of the country's image internationally, } \\
\text { transparency and reliability of the financial information disclosed. }\end{array}$ \\
\hline & & 1 & $\begin{array}{l}\text { Will allow information to be exchanged, assurance of reports and } \\
\text { application of tax techniques that are aligned with international } \\
\text { practices. }\end{array}$ \\
\hline & & 2 & Signals a more legally secure future for inspectors and inspectees. \\
\hline & & 1 & No response. \\
\hline & \multirow[t]{2}{*}{ Society } & 4 & $\begin{array}{l}\text { Ensures that resources be applied economically, efficiently, effectively, } \\
\text { in compliance with laws, regulations, and information free of } \\
\text { distortions. }\end{array}$ \\
\hline & & 2 & No response. \\
\hline \multirow[t]{2}{*}{ 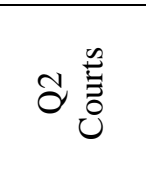 } & \multirow{2}{*}{$\begin{array}{l}\text { Brazil before } \\
\text { other } \\
\text { countries and } \\
\text { society }\end{array}$} & 10 & $\begin{array}{l}\text { Increase credibility and quality of work, professionalism in inspections, } \\
\text { institutional strengthening of external control and optimization of time } \\
\text { in which audits are performed. }\end{array}$ \\
\hline & & 7 & Did not respond. \\
\hline
\end{tabular}

Source: prepared with data from the research questionnaires.

The answers found were in accordance with studies on the theme, demonstrating that the bodies were aware of the importance of the international auditing standards to qualify public management and pointed out the relevance and credibility to stakeholders (Gørrissen, 2020 Hay \& Cordery; 2021, Dragustin \& Pitulice, 2021). Regarding Q2, the question addressing improvements was only made to the $17 \mathrm{TCs}$ that presented the situations: i) studied; ii) in progress 
and iii) completed. The recognition of the importance of adopting the NBASP is aligned with the motivations presented for initiating the process of adoption the standards.

\subsection{Difficulties in the NBASP implementation processes}

The goal was to verify the main difficulties in implementing the NBASP. Some difficulties (Table 5) were pointed out by the TCs (20).

Table 5

\section{Difficulties faced by the courts to implement the standards}

\begin{tabular}{c|l}
$\begin{array}{c}\text { No. of } \\
\text { response }\end{array}$ & Difficulties faced by the courts \\
\hline 6 & Resistance to the change in auditing standards by professionals. \\
\hline 6 & $\begin{array}{l}\text { Human resources, reorganization of administrative units and internal procedures, and lack of } \\
\text { knowledge of NBASP by professionals integrating the process. }\end{array}$ \\
\hline 2 & No relevant difficulties were faced during the process. \\
\hline
\end{tabular}

Source: prepared with data from the answers to Q2 of the survey.

The courts that had not initiated or were studying the process of implementing the NBASP were not questioned as to why they had not started the process, and they pointed out difficulties when asked about the reason for not adhering to the standards (Table 2).

As for the supporting institutions, none reported objections to the adoption of the standards. It was highlighted that there was a delay in the beginning of the process, but with the edition of the NBASP level 3 standards (2019), many of the TCs studied or even started the adoption process.

There were challenges arising from the resistance of more experienced professionals in relation to changes, in addition to the lack of human resources and their training, important points for the implementation highlighted in the literature and consistent with the different practices observed, even by the auditors of a single body (Azevedo \& Lino, 2018). The finding indicates an important issue to be addressed for the success of the process.

\subsection{Qualification of audit professionals}

The research verified the need to qualify audit professionals, the results of which are shown in Table 6. Both the institutions and the TCs recognized the importance of training for the process, reporting their participation in events and studies. It is understood that the courts that have not started the implementation process have not trained their professionals either.

Table 6

Need to train professionals for the new standards of the institutions

\begin{tabular}{c|c|l}
\hline Sector & $\begin{array}{c}\text { No. of } \\
\text { response }\end{array}$ & Professional training \\
\hline \multirow{3}{*}{ Supporting Institutions } & 4 & $\begin{array}{l}\text { Existence of committees that participate in events and congresses } \\
\text { promoted for the dissemination and study of the NBASP. }\end{array}$ \\
& 2 & They do not have information on training and choice of professionals. \\
\hline
\end{tabular}

\begin{tabular}{c|c|c|l}
\hline & $\begin{array}{c}\text { Studying the } \\
\text { possibility of } \\
\text { implementing the } \\
\text { NBASP. }\end{array}$ & 2 & $\begin{array}{l}\text { Workshops, lectures, collaborative training, and lectures on the NBASP } \\
\text { will be held and material on the subject will be distributed. }\end{array}$ \\
\cline { 2 - 3 } & $\begin{array}{c}\text { In the process of } \\
\text { implementing the } \\
\text { NBASP. }\end{array}$ & 6 & $\begin{array}{l}\text { No civil servants were trained for or appointed to this project. } \\
\text { available by the NBASP's supporting and issuing body, }\end{array}$ \\
\hline & 2 & $\begin{array}{l}\text { Participation in courses, discussion groups and guest training sessions on } \\
\text { the standards. }\end{array}$ \\
\hline
\end{tabular}


\begin{tabular}{l|l|l}
$\begin{array}{c}\text { Implementation } \\
\text { concluded. }\end{array}$ & 2 & Distance courses and on-site seminars.
\end{tabular}

Source: prepared with data from the research questionnaires.

The relevance of professional organizations stood out at this point (Reichborn-Kjennerud et al., 2019; Hay \& Cordery, 2020; Luz, Guarido, \& Sousa, 2021), as the IRB is constantly mentioned in events that are promoted and publications on the topic (IRB, 2020). Abacom and Audicon have the promotion and inventive of events with the participation of specialists among their purposes, proving relevant to the process.

\section{FINAL CONSIDERATIONS}

This study was conducted with the goal of analyzing the process of adopting international public sector auditing standards in Brazilian Audit Courts. It is understood that the objective was achieved, since the obstacles and benefits involved were identified, in addition to contributing with a basis for research on the subject. The analysis of the progress made by the TCs in implementing the NBASP has shown that efforts are being made towards this end, despite the fact that the use of the standards by all the bodies and the consequent achievement of the benefits for the Brazilian society arising from best practices are still a long way off.

Among the 33 Audit Courts in Brazil, only 20 cooperated with this research, which is one of its limitations. It was verified that only two (10\%) TCs of the sample have already concluded the implementation of the NBASP, $12(60 \%)$ are in progress and six $(30 \%)$ have not yet initiated the process. The results reinforced the reports of previous research about the differences between the practices of Brazilian bodies (Azevedo \& Lino, 2018; Lino \& Aquino, 2018; Lino \& Aquino, 2020; Nunes, Marcelino, \& Silva, 2019; Luz, Guarido, \& Sousa, 2021) and international comparisons (Manes-Rossi, Brusca, \& Condor, 2020; Cordery \& Hay, 2021).

Brazil is a country with continental dimensions, with important differences between its regions, which may result in different practices. In this sense, however, the findings regarding the vast availability of training, the support provided by organizations, and the absence of need for financial resources by the bodies that completed the process left doubts concerning the motivations of the TCs that have not yet initiated the process.

The formalization of the adoption of the standards by means of an internal regulation seems to be an important issue, highlighting the relevance of the interest of the body's management in directing efforts to change procedures.

As verified, the adoption of international auditing standards by the TCs is recognized as important for improvements in international partnerships and to increase the credibility and trust of society, which is relevant in view of the episodes of corruption identified in the country and the criticism for practices implemented by the agencies that are objected by society (Lino \& Aquino, 2020). However, the lack of response to the survey by the agencies denotes deficiency in adherence to the legislation in force, since Law No. 12,527, of November 18, 2011, establishes that passing on information requested by any citizen is mandatory, and noncompliance, in turn, contradicts the legitimation expected by the adoption of standards, thus compromising the advances in this direction, such as the adoption of NBASP 20 and 30, which emanate the principles of transparency and accountability with ethics management, completed by the TCs.

The results obtained have reported, in general, that Brazilian TCs seek to improve the quality of inspection, since most respondents have begun the process of implementing international standards, and there are joint actions implemented by support organizations. However, the lack of an estimate for the conclusion of this process by most respondents, as well as the contradictory behaviors verified, indicate that there is still a long path ahead. The creation of an independent supervisory body has the potential provide contribution in addressing the 
different practices and ensure the use of standards to improve audits (Lino, Azevedo, Aquino, \& Steccolini, 2021).

We emphasize that the results of this research can contribute to the advancement of the international auditing standard implementation process by highlighting the diverse and incipient situation by many TCs, in addition to analyzing points of support and obstacles to their success. For future works, it is suggested to analyze the phenomenon with the support of theoretical lenses, to study the specific adherence to each of the standards and to investigate whether, in addition to formalizing the implementation of the standards, the practice of the agencies are in line with them.

\section{REFERENCES}

Azevedo, R. R., \& Lino, A. F. (2018). O distanciamento entre as normas de auditoria e as práticas nos Tribunais de Contas. Sociedade, Contabilidade e Gestão, 13(2), 9-27. Recuperado de http://dx.doi.org/10.21446/scg_ufrj.v13i2.13665

Azuma, N. (2008). The framework of INTOSAI Government Auditing Standards: in the stream of international convergence. Government Auditing Review, 15(1), 77-97. Recuperado de https://www.jbaudit.go.jp/english/exchange/pdf/e15d05.pdf

Bardin, L. (2011). Análise de conteúdo (L. A. Reto, \& A. Pinheiro, Trad.; 70. ed.). São Paulo: Edições 70.

Caruana, J., \& Kowalczyk, M. (2021). The quest for audit quality in the public sector. Accounting in Europe, 18(1), 1-25. Recuperado de http://dx.doi.org/10.1080/17449480.2020.1757731

Cordery, C. J., \& Hay, D. C. (2021). Public sector audit in uncertain times. Financial Accountability \& Management. Recuperado de https://doi.org/10.1111/faam.12299

Dragustin, C., Pitulice, I., \& Stefanescu, A. (2021). Harmonisation and emergence concerning the performance audit of the EU member states' public sector. Romania's case. Sustainability, 13(7), 3673. Recuperado de http://dx.doi.org/10.3390/su1307367

Gørrissen, E. (2020). The role of the INTOSAI Development Initiative (IDI) in strengthening the capacity and performance of supreme audit institutions in developing countries. Journal of Public Budgeting, Accounting \& Financial Management, 32(4), 729-733. Recuperado de https://doi.org/10.1108/JPBAFM-08-2020-0146

Gustavson, M., \& Rothstein, B. (2013). Can auditing generate trust? The organization of auditing and the quality of government. In M. Reuter, F. Wijkstrom, B. Uggla (Eds.). Trust and organizations (pp. 41-63). New York: Palgrave Macmillan. Recuperado de https://doi.org/10.1057/9781137368812_3

Hay, D., \& Cordery, C. (2021) Evidence about the value of financial statement audit in the public sector. Public Money \& Management, 41(4), 304-314. Recuperado de https://doi.org/10.1080/09540962.2020.1729532

Hay, D., \& Cordery, C. (2020). The future of auditing research in the public sector. Journal of Public Budgeting, Accounting \& Financial Management, 33(2), 234-242. Recuperado de https://doi.org/10.1108/JPBAFM-09-2020-0164 
INTOSAI - International Organisation of Supreme Audit Institutions (2021). Recuperado de https://www.intosai.org/

IRB - Instituto Rui Barbosa. (2020). Normas Brasileiras de Auditoria no Setor Público (NBASP): nível 1: princípios basilares pré-requisitos para o funcionamento dos Tribunais de Contas brasileiros. Recuperado de https://irbcontas.org.br/biblioteca/nbasp-1/

IRB - Instituto Rui Barbosa. (2019). Normas Brasileiras de Auditoria do Setor Público (NBASP): nível 3: requisitos mandatórios para auditorias do setor público. Recuperado de https://irbcontas.org.br/nbasp/

IRB - Instituto Rui Barbosa. (2020). Sobre o IRB. Recuperado de https://irbcontas.org.br/sobre-oirb/

Kontogeorga, G. N. (2019). Juggling between ex-ante and ex-post audit in Greece: A difficult transition to a new era. International Journal of Auditing, 23(1), 86-94. Recuperado de https://doi.org/10.1111/ijau.12147

Lino, A. F., \& Aquino, A. C. B. (2018). A diversidade dos Tribunais de Contas regionais na auditoria de governos. Revista Contabilidade \& Finanças, 29(76), 26-40. Recuperado de https://doi.org/10.1590/1808-057x201803640

Lino, A. F., \& Aquino, A. C. B. (2020). Práticas não adequadas nos Tribunais de Contas. Revista de Administração Pública, 54(1), 220-242. Recuperado de https://doi.org/10.1590/0034761220190270

Lino, A. F., Azevedo, R. R., Aquino, A. C. B., \& Steccolini, I. (2021). Fighting or supporting corruption? The role of public sector audit organizations in Brazil. Critical Perspectives on Accounting, 8, 102384. Recuperado de https://doi.org/10.1016/j.cpa.2021.102384

López-Hernández, A. (2013). Normas profesionales de la INTOSAI: directrices de auditoría. Revista Auditoría Pública, 61(1), 9-24. Recuperado de https://asocex.es/wpcontent/uploads/PDF/Pag\%209-24\%20N\%C2\%BA\%2061.pdf

Luz, B. B. C., Guarido, E. R. F., \& Sousa, M. M. (2021). Legal, normativo e responsivo: frames no debate sobre a reforma dos Tribunais de Contas brasileiros. Revista de Administração Pública, 55(4), 861-880. Recuperado de https://bit.ly/395ogvj

Macagnan, C. B, Laureano, R. V, Rosso, V. P., \& Wartchow, D. (2020). Tribunais de Contas brasileiros são transparentes. Cuadernos de Contabilidad, 20(50). Recuperado de https://doi.org/10.11144/Javeriana.cc20-50.tcbt

Manes-Rossi, F., Brusca, I., \& Condor, V. (2020): In the pursuit of harmonization: comparing the audit systems of European local governments. Public Money \& Management, 1-11. Recuperado de https://doi.org/10.1080/09540962.2020.1772549

Nunes, S. P., Marcelino, G. F., \& Silva, C. A. T. (2019). Os Tribunais de Contas na interpretação da Lei de Responsabilidade Fiscal. Revista de Contabilidade e Organizações, 13(1), 1-15. Recuperado de https://doi.org/10.11606/issn.1982-6486.rco.2019.145151 
Reichborn-Kjennerud, K., González-Díaz, B., Bracci, E., Carrington, T., Hathaway, J., Jeppesen, K. K, \& Steccolini, I. (2019). Sais work against corruption in Scandinavian, South-European and African countries: an institutional analysis. The British Accounting Review, 51(5), 100842. Recuperado de https://doi.org/10.1016/j.bar.2019.100842

STN - Secretaria do Tesouro Nacional. (2018). Manual de Contabilidade Aplicada ao Setor Público. Recuperado de https://sisweb.tesouro.gov.br/apex/f?p=2501:9::::9:P9_ID_PUBLICACAO:31484

Speck, B. W. (2000). Inovação e rotina no Tribunal de Contas da União: o papel da instituição superior de controle financeiro no sistema político-administrativo do Brasil. São Paulo: Fundação Konrad Adenauer.

TCU - Tribunal de Contas da União. (2020a) Normas Brasileiras de Auditoria no Setor Público (NBASP). Recuperado de https://portal.tcu.gov.br/fiscalizacao-e-controle/auditoria/normasbrasileiras-de-auditoria-do-setor-publico-nbasp/

TCU - Tribunal de Contas da União. (2020b). Normas Internacionais das Entidades Fiscalizadoras Superiores (ISSAI) - ISSAI em português. Recuperado de https://portal.tcu.gov.br/fiscalizacao-e-controle/auditoria/normas-internacionais-dasentidades-fiscalizadores-superiores-issai/ 